Once you have Acrobat Reader open on your computer, click on the Comment tab at the right of the toolbar:

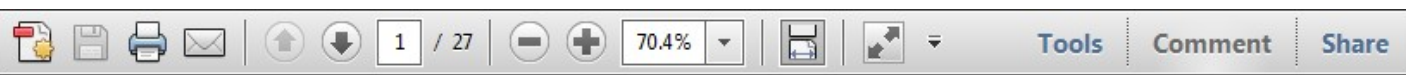

This will open up a panel down the right side of the document. The majority of tools you will use for annotating your proof will be in the Annotations section, pictured opposite. We've picked out some of these tools below:

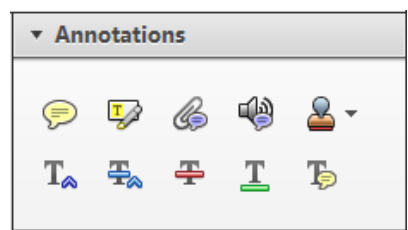

\section{Replace (Ins) Tool - for replacing text.}

Trikes a line through text and opens up a text box where replacement text can be entered.

\section{How to use it}

- Highlight a word or sentence.

- Click on the Replace (Ins) icon in the Annotations section.

- Type the replacement text into the blue box that appears.

ıdard tramework for the analysis of $\mathrm{m}$ icy-Nevertheless, it also led to exog،

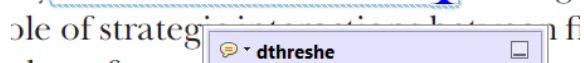
aber of comp 08/06/2011 15:58:17 $\quad$ O

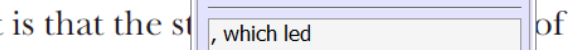
nain compo: be level, are exc nc

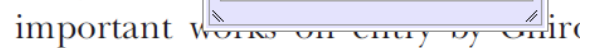
M henreforth) ${ }^{1}$ we onen the 'hlarl t

3. Add note to text Tool - for highlighting a section to be changed to bold or italic.

T. Highlights text in yellow and opens up a text box where comments can be entered.

\section{How to use it}

- Highlight the relevant section of text.

- Click on the Add note to text icon in the Annotations section.

- Type instruction on what should be changed regarding the text into the yellow box that appears.

namic responses of mark ups ent with the VAR evidence

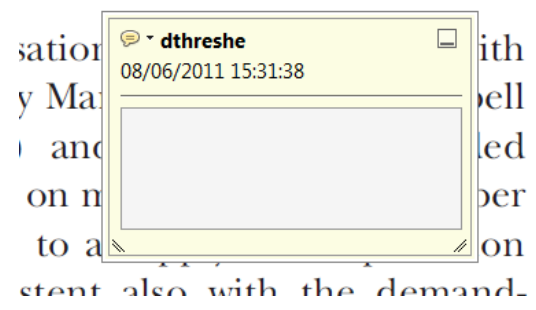

\section{Strikethrough (Del) Tool - for deleting text.}

T. Strikes a red line through text that is to be deleted.

How to use it

- Highlight a word or sentence.

- Click on the Strikethrough (Del) icon in the Annotations section.

there is no room for extra protits al s ups are zero and the number of zet) values are not determined by Blanchard and Kiyotaki (1987), sfect competition in general equilil ts of aggregate demand and supply lassical framework assuming monol ean an evorensuc numher of firme

\section{Add sticky note Tool - for making notes at} specific points in the text.

\section{Marks a point in the proof where a comment} needs to be highlighted.

How to use it

- Click on the Add sticky note icon in the Annotations section.

- Click at the point in the proof where the comment should be inserted.

- Type the comment into the yellow box that appears.

iailu ailu suppiy siluks. Hivsl vi

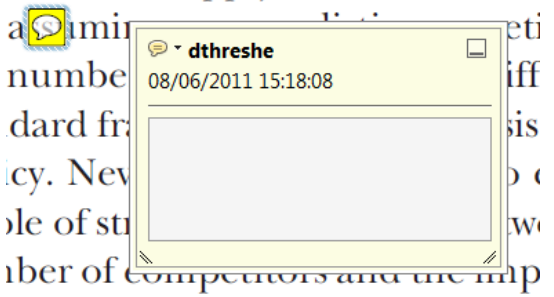

lber of "

is that the structure of the sects 
5. Attach File Tool - for inserting large amounts of text or replacement figures.

Inserts an icon linking to the attached file in the appropriate place in the text.

\section{How to use it}

- Click on the Attach File icon in the Annotations section.

- Click on the proof to where you'd like the attached file to be linked.

- Select the file to be attached from your computer or network.

- Select the colour and type of icon that will appear in the proof. Click OK.

E N D

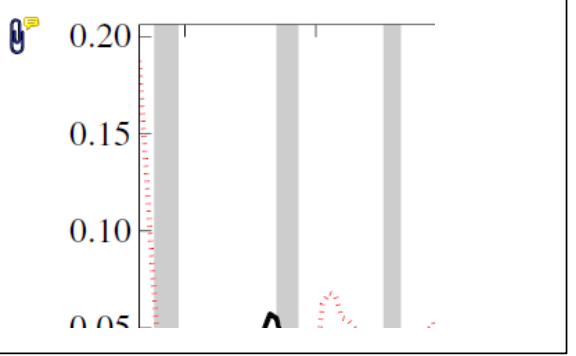

6. Drawing Markups Tools - for drawing shapes, lines and freeform annotations on proofs and commenting on these marks.

Allows shapes, lines and freeform annotations to be drawn on proofs and for comment to be made on these marks.

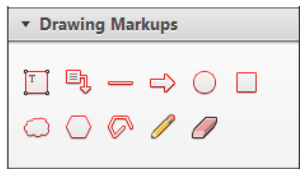

How to use it

- Click on one of the shapes in the Drawing Markups section.

- Click on the proof at the relevant point and draw the selected shape with the cursor.

- To add a comment to the drawn shape, move the cursor over the shape until an arrowhead appears.

- Double click on the shape and type any text in the red box that appears.

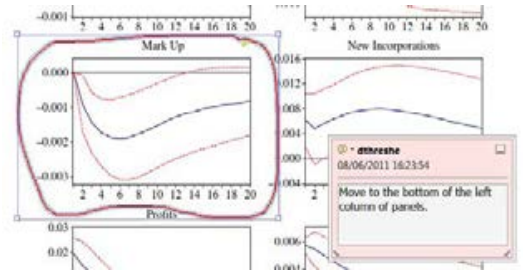




\begin{tabular}{|l|c|c|l|l|l|}
\hline \multirow{2}{*}{$\mathcal{2}$} & G E O J & \multicolumn{1}{|c|}{$\mathbf{1 2 2 0 3}$} & \multirow{2}{*}{ WILEY } & Dispatch: 30.11 .16 & CE: Wiley \\
\cline { 2 - 3 } \cline { 5 - 6 } & Journal Code & Manuscript No. & & No. of pages: 12 & PE: Bhagyalakshmi \\
\hline
\end{tabular}

The Geographical Journal, 2016, doi: 10.1111/geoj.12203

\title{
Landscape narratives in practice: implications for climate change adaptation
}

\author{
VERA KÖPSEL*, CORMAC WALSH* AND CATHERINE LEYSHON† \\ *Institute of Geography, University of Hamburg, Bundesstr. 55, 20146 Hamburg, Germany \\ E-mail: vera.koepsel@uni-hamburg.de,cormac.walsh@uni-hamburg.de \\ +Department of Geography, University of Exeter, Cornwall Campus, Treliever Road, Penryn TR10 9EZ \\ E-mail: c.brace@exeter.ac.uk \\ This paper was accepted for publication in November 2016
}

\begin{abstract}
Research on the societal dynamics of climate change adaptation has advanced during recent years from merely focusing on technical and economic factors to taking into consideration people's individual perspectives and personal values. Within this context a growing literature on the relationship between people's place attachment and climate change adaptation has emerged. This literature seeks to explain how individuals' relationships with the places in which they live influence current and potential future responses to climate change at the local scale. Nevertheless, critical limitations are evident in the conceptualisation of place and people-place relationships within this literature. In particular, differences between individual place constructions and their possible implications for landscape management are given insufficient attention. To address these shortcomings, we mobilise research on the societal construction of landscapes to uncover how actors in landscape management perceive 'their' places and changes to them. Drawing on qualitative interviews with key actors in landscape management in Cornwall (UK), we present four contrasting narratives about local landscapes and climate change and highlight their potential implications for adaptation to climate change.
\end{abstract}

KEY WORDS: climate change adaptation, landscape management, landscape perception, place attachment, narratives, Cornwall (UK)

\section{Introduction}

The stories of who we are, which are often connected to the stories of where we live, act as a backdrop against which decisions are made. These decisions can affect both the physical and symbolic constitution of a place.

\section{Alkon $(2004,165)$}

$\mathrm{n}$ times of a changing climate, future landscape change must be understood in terms of the complex interaction of socioeconomic and environmental processes such as storms, flooding, shoreline erosion and physical mitigation and adaptation measures undertaken by humans (Adger et al. 2013; Agyeman et al. 2009; Climate UK 2012). To the local population of affected areas, such changing landscapes are lived spaces and places of everyday life, valued for cultural heritage and personal attachments (Adger et al. 2009 2011; Brace and Geoghegan 2010; Devine-Wright 2014; Ratter and Gee 2012). It is increasingly recognised in human geography and related disciplines that societal adaptation to environmental changes requires public participation and close attention to the specificities of individual places. Plans for climate change adaptation developed by national committees often fail to address the particular problems on the ground, or are not accepted by local populations (Adger et al. 2009 2013). A growing number of studies are therefore dedicated to understanding processes of climate adaption as culturally embedded within specific local and regional contexts.

In her article on heritage narratives in California, Alkon (2004) shows that a dominant story about a place can strongly influence its governance. Here, we argue that competing narratives about landscape, change and climate have implications for climate change adaptation at the local level. The local construction of climate change is grounded in the landscape through which this global phenomenon is given local meaning (Brace and Geoghegan 2010; Greider and Garkovich 1994). In this paper we focus 
on constructions of place and landscape among actors in landscape management ${ }^{1}$. Previous studies have demonstrated the influence of particular narrative frames in structuring policy debates on nature protection and environment-society relations (Greider and Garkovich 1994; Hajer 1995; Leyshon and Walker forthcoming). However, subjective constructions of place and landscape among governance actors remain under-researched in work on climate change adaptation. While insights from the rich body of place attachment literature have already travelled into the field of climate adaptation research (e.g. Amundsen 2015; Devine-Wright 2014), two perspectives are under-developed but crucial for understanding the societal dynamics of climate adaptation on the local level. First, existing research on place attachments often overlooks what happens when different attachments come into conflict with each other. Second, although the attachments and meanings people associate with places lie at the core of this field, place is problematically separated out from its constitutive social relations (Devine-Wright 2015; Tomaney 2015).

We demonstrate that differing personal perceptions of places and landscapes can lead to contrasting approaches to climate adaptation amongst landscape managers. The application of adaptive measures - even those drafted by national bodies always takes place on the ground (Agyeman et al. 2009). Local staff of national or regional landscape management organisations are bound by organisational guidelines and policies, but their decisions are embedded in local framings of climate change and the places in which they live and work. Thus, local landscape managers act at the interface between expert thinking and contextualised, culturally mediated, personalised understandings of climate change and adaptation (Geoghegan and Leyshon 2014). It is these hybrid perceptions of change to places and landscapes that we argue play an important role in local decisionmaking around climate change adaptation. To explore them further, we turn to a narrative approach - an analytical tool from sociological studies, but so far rarely applied in geographical research on climate change adaptation (Alkon 2004; Soliva 2007). A narrative approach exposes contrasting stories about what a landscape is, what characteristics are attached to it, and what it means when it is altered by a changing climate. Before explaining the use of narratives as a tool of qualitative inquiry, we first embed our research into a wider theoretical framework of place attachment and constructivist landscape research.

\section{Place attachment and climate adaptation}

For about three decades scholars from the social sciences generally and human geography in particular have been researching the connections bet- ween people's identities, their attachment to places, and their responses to change (Devine-Wright 2013). For Agyeman et al. (2009), it is the consideration of these attachments to places which is lacking in the design and application of policy decisions around climate change, often resulting in a feeling of neglect among the local population. Yet, a changing climate threatens place-based cultural values by physically altering locations to which people feel attached (Adger et al. 2011). Other studies indicate that people are more likely to fight for places when the symbolic meanings associated with them are threatened by change (Burley et al. 2007; DevineWright 2014; Walker and Ryan 2008). Thus, existing research into the role of place attachments and emotional bonds with places is an important basis for understanding the influence that people-place relationships have on societal responses to climate change. These studies, however, with few exceptions, assume place to be a given, an object outside of social relations. The literature thus focuses on processes of attachment and belonging to place and fails to address the ways in which places themselves are constructed through socio-spatial processes and practices.

The literature focusing on place attachment introduced above acknowledges the need to consider both societal and individual values in processes of environmental management and decisionmaking. 'Elucidating place meaning', Fresque-Baxter and Armitage (2012, 260) argue, 'can help to explore how people feel about certain types of activities'. This becomes particularly important when adaptation measures implemented by one group impact negatively on what another group values (O'Brien 2009). In this paper, we show that such divergent values are likely to be found between actors from different organisations, impacting on their approaches to adaptive landscape management under a changing climate. To comprehend better the local contexts in which climate adaptation happens on the ground, it is vital to expose the different perspectives on the places in focus that exist among actors in landscape management. In this context, a conceptual framework from another line of research deeply rooted in human geography provides helpful insights: that of constructivist landscape research.

\section{Landscapes as societal constructs}

In the UK and elsewhere, many environmental management policies and interventions are designed and applied at the 'landscape scale' (see e.g. Natural England 2011). This approach mirrors essentialist understandings of landscapes as discrete spatial entities, commonly found in the natural sciences. Another approach has emerged among sociologists and human geographers during the past decades which conceptualises landscapes as lived and 
subjectively perceived constructs rather than focusing on the quantifiable, 'objective' characteristics of spaces (compare e.g. Ingold 2010; Gailing 2012; Kühne 2013). We draw on recent German-language literature which places analytical attention on the relationship between the social and the material in the construction of landscapes. Following Kühne's (2013) moderate social constructivist perspective, we understand landscapes as social constructs individually and collectively created in close relation to the physical environment (Gailing 2012; Kilper and Gailing 2013; Kühne 2013). Which elements of a physical space are considered part of a landscape, and what meanings are associated with them, can vary significantly between different individuals and groups within a society. Understanding the role of the physical, material environment in landscape construction contrasts with a discursive constructivist approach in which material aspects only become 'socially relevant' if they are communicated through discourse (Gailing and Leibenath 2015, 131). Rooted in a sociology of knowledge perspective following Berger and Luckmann (1966), the social constructivist strand of landscape research conceptualises landscape constructions as an amalgamation of a person's cultural socialisation, individual experiences, and professional education (Kühne 2013). It asks both how different groups of people subjectively perceive landscapes based on their cultural values and worldviews, as well as how different sectoral systems within a society - e.g. urban planning or nature conservation- construct landscapes and with what (political) purpose (Gailing 2012; Kilper and Gailing 2013).

Kühne (2013) and Kilper and Gailing (2013) see the construction of landscapes as nonlinear, mutually interdependent processes consisting of (1) subjective landscape constructions of individuals; (2) collective constructions based on shared societal understandings of landscapes; and (3) physicalmaterial alterations of the environment through resulting societal actions. Landscape change thus results from the interplay between locally contextualised subjective, collective and physical-material construction processes. These constructions are deeply embedded in how the current landscape is societally and individually interpreted, making the process of landscape construction both reciprocal and continuous (Greider and Garkovich 1994; Kilper and Gailing 2013; Kühne 2013).

Greider and Garkovich (1994) appeal to the importance of contrasting perceptions of landscapes in negotiation processes around environmental management. Constructivist landscape research in the context of climate change adaptation remains underdeveloped, notwithstanding. One exception, in the British context, is Brace and Geoghegan's (2010) call to investigate how everyday practice in the landscape influences local perceptions of the global phenomenon of climate change. The authors call for climate change research which is 'grounded and localized through the concept of familiar embodied, practised and lived - landscapes of everyday life' and argue that focusing on the material manifestations of a changing climate in the landscape helps to re-focus on the actual physical spaces in which climate change takes place ( $p$. 296). We seek to take up their demand to 'ground the idea of climate change in landscape' (p. 293) by revealing differing constructions of local landscapes and their implications for climate change adaptation.

\section{Narratives in qualitative research}

Alkon (2004, 148) understands narratives about places as 'emergent stor[ies] appropriated by actors that make ... choices seem relevant and natural'. Soliva's $(2007,63)$ work on landscape change in the Swiss Alps shows that '[p]eople tell different "stories" about changes in land use, landscape ... and about how these changes interdepend. Their perception and assessment of past changes influence the way they think about present changes and future developments'. In the context of landscape and climate change, Leyshon and Geoghegan (2012) found that such narratives can circle around seemingly insignificant structures in the landscape in this case cattle grids on the Cornish Lizard peninsula (UK) - and yet have decisive weight in different actors' understandings of climate change. The focus of working with narratives, DeSilvey (2012, 34) argues, is not on comparing the stories people tell with a presumed 'truth', but on understanding the storylines and underlying motifs in a certain narrative frame. Examining how different actors in landscape management frame the phenomena which are the focus of their work, Leyshon and Walker (forthcoming) argue that different storylines around a problem in its local context decisively shape management outcomes. Thus, uncovering different narratives about landscape can provide valuable insights into the shared and contrasting ways in which actors in landscape management make sense of the places where they live and work, changes to these places, and climate change. Although the narrative approach is an established approach in the qualitative social sciences that has already been used to research how people make sense of the phenomenon of climate change (cf. Daniels and Endfield 2009), its potential for understanding societal processes of adaptation to climate change is to date unexplored.

Methodologically, the use of narratives demands a qualitative, interpretative inquiry. The policy narrative outlined below is based on an analysis of 
policy documents published by Cornwall Council following an interpretive policy analysis approach (see Wagenaar 2016). Nineteen semi-structured qualitative interviews conducted in Cornwall (UK) in late 2015 revealed competing constructions of the local landscapes under a changing climate. The interviewees were identified through a purposive sampling strategy as key actors in local landscape management either due to their position within respective organisations or because of their eng agement as Parish or Cornwall Councillors (Richie and Lewis 2003, 78). From a constructivist landscape research perspective, the uncovered nar ratives form a bridge between individual perceptions of landscapes and collective constructions shared across a society ${ }^{2}$. The identification of different overarching narratives about landscape and climate change emerged from a three-step process similar to that suggested by Feldman et al. (2004). First, individual stories about landscape, landscape change, climate change, and adaptation were identified within each interview. Second, these separate stories were analysed relative to each other to identify the larger line of argument stretching through the entire interview. Third, storylines circling around similar phenomena and following similar internal logics were grouped together to form what Feldman et al. (2004) term 'encompassing narratives'.

\section{The case study region: Cornwall (UK)}

Cornwall is a rural peninsula in the South West of England stretching into the Atlantic Ocean, and with a history of human settlement since prehistoric times. With a population of half a million, Cornwall's economy is largely based on agriculture and tourism, and thus on its physical environment. Aside from a few small towns, Cornwall is characterised by scattered villages, farms and a variety of protected landscapes (Cornwall Council 2012 2016). Climate change impacts are already visible in the Cornish landscape in the shape of coast and catchment flooding (Environment Agency 2012). Climate change projections for South West England forecast a significant increase in such episodes, along with more frequent extreme weather events and a shift in rainfall patterns (Climate UK 2012; Environment Agency 2012). Flood management is the responsibility of various organisations in Cornwall, including the Environment Agency, Natural England and Cornwall Council, but an overarching climate adaptation strategy for the area does not exist. Although the Council emphasises the need for 'significant adaptation in the design and location of buildings and infrastructure', official statements about climate change are mainly limited to mitigation and renewable energy development as a profitable income source (Cornwall Council 2015b).

Over one third of Cornwall's land area is under designations such as AONB or $\mathrm{SSSI}^{3}$, with sections of its 290 miles of coastline managed by the National Trust (Cornwall Council 2016). In view of its economic dependence on agriculture and tourism, landscape does not only have particular relevance for local policymaking and planning, but also plays an important role in Cornwall's regional identity, branding and economic profile (Cornwall Council 2016). The prominent 'Poldark' television series, for example has contributed significantly to establishing Cornwall's industrial heritage from the sixteenth to the nineteenth century mining era and related relict landscapes, as foundational elements of Cornish identity (Beer 2016). Thus, considering the prominent role which the issue of landscape has in the region and its exposure to climate change impacts, Cornwall serves as a particularly suitable example for researching the relevance of differing landscape constructions for climate adaptation.

As we will show in the following section, one particular landscape narrative is actively promoted by Cornwall Council and serves as the basis for a variety of policy decisions (Cornwall Council 2015a 2016). However, it is not the only one that exists in the region. Entering into dialogue with local actors in landscape management exposes competing narratives about the Cornish landscapes and climate change which challenge the way in which Cornwall is being portrayed by its Council. We will now introduce the Council's policy narrative as well as the landscape narratives derived from the empirical data before we outline their implications for climate change adaptation.

\section{Uncovering landscape narratives}

Along with policy documents by Cornwall Council, the interviews conducted in Cornwall revealed a number of competing narratives about the local landscapes. These different landscape constructions are based on varying understandings of nature, the human-environment relationship, and the impacts climate change will have on Cornwall. The narrative officially promoted by Cornwall Council in various documents and in their Local Plan 2010-2030 with far-reaching policy implications - thereby stands against a number of other framings of the Cornish landscapes. Acknowledging that these narratives are only a selection of all existing perspectives on Cornwall's landscapes, we will now introduce this official policy narrative, and then contrast it against three different landscape narratives identified from the empirical data: (1) the natural landscape; (2) the lived landscape; and (3) the productive landscape. 


\section{The policy narrative}

The policy narrative promoted by Cornwall Council ${ }^{4}$ highlights the important role landscape plays in Cornwall's regional identity and economic development. It centres on distinctiveness and diversity, natural and cultural heritage, and an ethos of protection. Cornwall is presented as a place shaped by human activities benefitting from the area's natural resources for thousands of years. The relicts of this longstanding human-environment relationship make up today's landscape character: fishing villages, ancient field patterns and the ruins of engine houses from the mining era complement a stunning coastline and a beautiful natural environment (Cornwall AONB Partnership 2011; Cornwall Council 2011 2016). For the Council, landscape is about the relationship between people and place ... It can mean a patch of local green space as much as a mountain range. The Cornish landscape is stunning, diverse, unique' (Cornwall Council 2014). From this perspective, the local landscapes serve a threefold purpose: they make up an important part of the regional identity, accommodate wildlife and cultural heritage, and thus underpin Cornwall's economic activities, particularly in the tourism sector. The recently drafted 'Cornwall Local Plan 2010-2030' clearly connects the beauty and uniqueness of the Cornish landscapes with their potential for economic benefit by 'attract[ing] locals, visitors and businesses' (Cornwall Council 2016, 9). A key strategy to achieve higher economic value of the landscape is the preservation of local distinctiveness through characteristic building styles and the protection of existing heritage sites. The Council's understanding of Cornwall's landscapes is thus given a clear policy imperative (Cornwall Council 2016, 9).

While portraying the area's landscapes as a visually attractive mosaic of natural and cultural heritage, the official policy narrative masks the exploitation of Cornwall's natural resources and environmental damage through past industrial activities with a layer of romanticised constructions of a people living and working in harmony with a beautiful landscape. This perspective entails a clear imperative to protect the historic landscape character against inappropriate development and greying-out of local distinctiveness (Cornwall Council 2011 2014 2015a). This focus on preserving the beauty of Cornwall's landscapes comes with an ambivalent relationship to change. While the importance of visually attractive landscapes as an economic resource is acknowledged, an increasing number of large-scale housing and renewable energy projects has been permitted by the Council's planning department in recent years (Cornwall Council 2011). Seemingly torn between preservation and economic development, the local landscapes are seen as both the foundation of Cornwall's regional identity and its main economic resource. Thus, the policy narrative outlined here provides indications of unresolved underlying tensions and suggests the coexistence of a diverse plurality of landscape constructions informing the policy approach within Cornwall.

\section{Coexisting landscape narratives in Cornwall}

The interview data clearly show that differing understandings of the Cornish landscapes exist alongside the Council's policy narrative. The considerable significance of Cornwall's landscapes for its regional identity, however, is mirrored in all interviews with actors in local landscape management. No matter what story about landscape and climate change develops, all collectively share an appreciation of the Cornish landscapes as visually attractive, and express strong emotional bonds to Cornwall as a place. Although interviewed in their professional roles, all interviewees relate to Cornwall's landscapes through very personal, experiential stories:

It's quite rugged and robust and tough. You DO feel nature here! And I like it! I'm looking forward to wild nights walking on the beach in the dark with a torch and $\mathrm{my}$ dog in the winter...

\section{I-5, Visit Cornwall}

I'm an environmental consultant, that attaches me to the landscape a lot, particularly this one. Because my main subject is the mining landscapes and Cornish hedges. And I used to be a Cornish Hedger once - the smell and the noise of it is really lovely

I-10, Parish Councillor

This melding of professional and personal accounts is particularly interesting against the background of the growing debate challenging the role and objectivity of experts both within and beyond the field of human geography (see e.g. Geoghegan and Leyshon 2014). Surprising commonalities between the interviewees' choice of words indicate a shared prevalent discourse in the region about the iconic visual elements of its landscape: on the collective level, Cornwall is constructed as a beautiful maritime area with rolling hills, pretty estuaries, a rugged and stunning coastline as well as important cultural and industrial heritage from past eras. Although all interviewees share a high appreciation for aesthetic qualities of Cornwall's landscapes and highlight the role of its industrial heritage, further analysis reveals substantial differences in the interpretations of these landscapes. Taking a closer look at the individual constructions of the local landscapes and changes to them, the commonalities 
soon end and different narratives unfold. As outlined on p. subjective landscape constructions are results of individual combinations of socialisation, experiences and education (see Kühne 2013). It is therefore no surprise that none of the interviewees' perceptions of Cornwall's landscapes resemble each other entirely. While each story is coloured by personal experiences, certain stories do focus on very similar landscape elements and vocabulary. To crystallise the different narratives, we identified key phenomena addressed in each interview; emotions articulated in relation to the landscape, perceptions of change as well as implications of all these for landscape management (see also Feldman et al. 2004). By particularly emphasising the way in which the relationship between the landscape and human activity is conceptualised, as well as the overarching goals of landscape management, we uncovered three distinct narratives of Cornwall's landscapes which contrast with the policy narrative: landscapes as natural systems; as lived-in places; and as spaces of production. The results of the interview analysis are summarised in Table 1. As Soliva (2007) and Leyshon and Walker (forthcoming) suggest, each of these narratives has different implications for landscape management and implies distinct approaches to climate adaptation. In the following paragraphs we will expand on these three perspectives on Cornwall's landscapes to outline their implications for climate change adaptation.

The natural landscape narrative In the policy narrative by Cornwall Council, Cornwall's landscape is a representation of its natural beauty and past human activity on the one hand and a valuable economic resource on the other. The natural landscape narrative, however, understands Cornwall's landscape in terms of wildlife and habitats, fields and wetlands, and a distinct assemblage of plant and animal species. Referring to management at the 'landscape scale' and habitat types with clear boundaries, this narrative represents a classic natural-scientific understanding of landscapes. The Cornish landscape is viewed as a sensitive natural environment under threat which needs protection through specific management. To Interviewee 11, an employee of the Cornwall Wildlife Trust:

\footnotetext{
... the way the landscape looks is largely a result of the wildlife and of land use. Many of the areas that you think of as being important for the landscape are also really important from a wildlife and biodiversity point of view -coastal habitats, moorlands, woodlands.
}

In this narrative, the natural and the human are perceived as largely separate systems - the former under pressures from the latter. Constructing the landscape in terms of natural systems influenced by human activity places emphasis on its importance for sheltering local wildlife and ensuring environmental resilience. The interviewees following this narrative express attachment primarily with natural elements of the landscape and are concerned about unsustainable practice, especially in the farming sector, which leads to wildlife and habitat loss. This concern comes with a feeling of custodianship over the natural environment. Interviewee 1, a Lead Advisor for Natural England, perceives the Cornish landscape as vulnerable to unsustainable management practices:

You only need three months of rain and you've lost your top soils. And you've damaged important freshwater ecosystems ... But people have this need to develop land. And there's not given much thought on sustainability issues. ... That's one of the reasons why we do what we do. We're looking after it, that's very important.

Change here is perceived as a natural process leading to changes in habitats and ecosystems. As the vulnerabilities of Cornwall's natural environment are largely caused by manmade changes, however, it is understood to be the responsibility of management interventions to improve wildlife and habitat resilience. The landscape is thus seen as a mosaic of fragile natural systems in need of protection from harmful human intervention. Thus, the aims of landscape management are to create a resilient natural environment, reduce adverse human impacts and restore habitat connectivity.

The lived landscape narrative for other interviewees, Cornwall's landscapes are much more the result of interactions between human activities and the natural environment. From this perspective, landscape is a reflection of the long history of human settlement in Cornwall, a braid of natural and manmade elements, and a place for local communities to live and work in. This perspective mirrors the ways in which Rose and Wiley (2006, 475) theorise landscape as 'embodied, perceived, affected' places of dwelling. For Interviewee 18 who works for the Cornwall AONB Partnership:

\footnotetext{
the landscape ... influences what humans do ... The protected landscapes make provision for sustainable communities that live in the area. And you can't put a ring around the landscape and say 'We can't do anything in here' - people live there! ... But we're still in that sort of old track of 'Yeah, but we can't do this, because it's protected!'
}

Whereas in the Council's policy narrative the historic landscape is portrayed as an important economic resource in need of protection, the notion of preservation is seen more critically in the lived landscape narrative. Here the landscape, both natural and manmade, is perceived as the result of 
Table 1 Landscape narratives - overview

\begin{tabular}{|c|c|c|c|}
\hline Phenomena addressed & Emotional articulation & Perception of change & Management implications \\
\hline \multicolumn{4}{|l|}{ The policy narrative } \\
\hline $\begin{array}{l}\text { Natural and cultural } \\
\text { heritage; long history of } \\
\text { settlement; aesthetic } \\
\text { qualities of landscape; } \\
\text { economic benefits; } \\
\text { regional Identity; } \\
\text { landscape designations } \\
\text { as proof of uniqueness }\end{array}$ & $\begin{array}{l}\text { Positive, persuasive } \\
\text { wording in the policy } \\
\text { document; highlighting } \\
\text { the importance of its } \\
\text { landscapes for Cornwall; } \\
\text { omits negative } \\
\text { connotations, e.g. } \\
\text { regarding mining era }\end{array}$ & $\begin{array}{l}\text { Important to maintain } \\
\text { distinctive character of } \\
\text { Cornwall's landscapes; need } \\
\text { for resilience to change of } \\
\text { whatever sort; demand for } \\
\text { sustainable approach to } \\
\text { change }\end{array}$ & $\begin{array}{l}\text { Focus on maintaining local } \\
\text { distinctiveness clashes with } \\
\text { need for economic } \\
\text { development; local design } \\
\text { guides for building; } \\
\text { attempt to integrate social, } \\
\text { economic and } \\
\text { environmental } \\
\text { sustainability }\end{array}$ \\
\hline \multicolumn{4}{|l|}{ The natural landscape } \\
\hline $\begin{array}{l}\text { Wildlife and habitats; } \\
\text { farming, fields, land use; } \\
\text { hedgerows, wet-lands; } \\
\text { farmland versus } \\
\text { biodiversity; rare plant } \\
\text { and animal species; } \\
\text { management at } \\
\text { landscape and }\end{array}$ & $\begin{array}{l}\text { Attachment to natural } \\
\text { elements of the land- } \\
\text { scape; responsibility for } \\
\text { healthy wildlife; concern } \\
\text { about unsustainable } \\
\text { practice and wildlife loss; } \\
\text { concern about } \\
\text { unsustainable }\end{array}$ & $\begin{array}{l}\text { Change is natural and } \\
\text { inevitable; change in } \\
\text { farming practice emphasised; } \\
\text { critiquing increase in built } \\
\text { development; manmade } \\
\text { change and practices } \\
\text { endanger healthy habitats }\end{array}$ & $\begin{array}{l}\text { Sustainability, resilience; } \\
\text { fragile landscape; } \\
\text { protection and } \\
\text { custodianship; wildlife and } \\
\text { habitat loss; shared } \\
\text { responsibility; managing } \\
\text { the landscape for species } \\
\text { and habitat connectivity }\end{array}$ \\
\hline
\end{tabular}

Humans = outside the landscape, influencing it externally

Landscape management $=$ protecting and restoring habitats for healthy wildlife

\section{The lived landscape}

Manifestation of human
practice in the natural
environment; basis for
and result of human
dwelling; place for
communities to live and
work in; expression of
past human activity and
local distinctiveness;
significant cultural
heritage of past fishing
and mining activities

$\begin{array}{ll}\text { Attachment to relicts of } & \text { Landscape as living and lived- } \\ \text { past human practice; } & \text { in; change is a natural by- } \\ \text { landscape as important } & \text { product of human dwelling; } \\ \text { part of Cornish identity; } & \text { critiquing 'greying out' of } \\ \text { sadness about loss of } & \text { local distinctiveness; } \\ \text { local distinctiveness; } & \text { landscape and cultural } \\ \text { sense of belonging; } & \text { practice in it change } \\ \text { Cornwall as a special } & \text { concurrently; critiquing } \\ \text { and unique place due to } & \text { short-sighted and } \\ \text { long-standing history of } & \text { indistinctive built } \\ \text { human activity and } & \text { development } \\ \text { natural beauty } & \end{array}$

Landscape as living and lived- Interaction between people and landscape; cultural practice; management at local level; focus on communities and their activities; local distinctiveness; responsibility for future generations

Humans = living in the landscape, their activities reciprocally shaping and being shaped by it

Landscape management $=$ embracing change, but preserving local distinctiveness through sustainable human practice

\section{The productive landscape}

$\begin{array}{ll}\begin{array}{l}\text { Intensive farming, food } \\ \text { production; primarily }\end{array} & \begin{array}{l}\text { Utilitarian understanding of } \\ \text { landscape; no high } \\ \text { manmade; highly }\end{array} \\ \begin{array}{l}\text { attachment expressed; no } \\ \text { developed and }\end{array} & \text { notions of romantic or } \\ \text { industrialised; barely any } & \text { aesthetic in landscape } \\ \text { bits of nature left } & \text { description; } \\ \text { anywhere; subject to } & \text { disappointment in } \\ \text { exploitation through } & \text { agencies for } \\ \text { mining and agriculture; } & \text { unsustainable } \\ \text { purpose of landscape is } & \text { management and } \\ \text { extraction of food and } & \text { overprotection; dislike of } \\ \text { other goods } & \text { emotional debates about } \\ & \text { landscape management }\end{array}$

Change is positive and natural, but not much change noticed in recent decades; large built structures in the landscape are not a problem; strong critique of efforts to preserve relicts of the past
Agricultural use, functionality, human modification; food production; critique of preservation; need for renewables in the landscape; landscape $=$ resource; scientific debates and factual decisions

Humans = living off the landscape, replacing nature with economic activity

Landscape management $=$ providing food and goods for people 
past and current cultural practice in Cornwall. Since such cultural practice takes various shapes, so the argument arises that there are many perceptions of these landscapes among the local population. The relationship between the landscape and its inhabitants is reciprocal, and continuous change is seen as a natural consequence of human dwelling. Interviewee 17, Flood Resilience Manager for the Environment Agency, explains:

The landscape ... is an interaction between where we work with the land and where we build ... If you look at our fishing communities for example or the mining communities, the landscape has shaped those communities - where they are, why they're there ... why they were facing the challenges they did.

The human and the natural system are viewed as intertwined, jointly constituting Cornwall's landscapes. This understanding of landscape as a preliminary result of human dwelling leads to an acceptance of change both through societal developments as well as natural processes. Since Cornish landscapes as relicts of past human activity are viewed as an important part of the regional identity, interviewees following the lived landscape narrative express sadness and concern about the greying-out of local distinctiveness through largescale housing and supermarket developments and the loss of local shops and gastronomy. Consequently, the aim of landscape management is to embrace and work with change, but preserve local distinctiveness through sustainable human practice in the landscape.

The productive landscape narrative These two narratives - even if to different extents - both acknowledge the natural environment as an important part of what constitutes the Cornish landscapes. The productive landscape narrative, however, reveals a divergent perspective on the natural elements of the local landscapes. Interviewee 3, a Parish Councillor born in Cornwall and running a family farm, has a very contrasting perception of the place where he lives. He sees the land as considerably shaped through intensified farming, and thus as a surface for economic activity. Having a largely functional view of the landscape, his description of the landscape is free of romantic or aesthetic notions:

I would describe it as a highly developed post-industrial landscape ... There is very, very little what you might call 'natural' about our landscape at all. I would think there is hardly one square foot of the county which has not been very, very heavily modified by men.

Also Interviewee 4, an elected Cornwall Councillor representing three rural villages on Cornwall Council, has a very sober view of the local landscapes. Although not having a background in farming or land management, to him the landscapes of Cornwall:

... have been affected by men's activities over centuries and over thousands of years, there are not many primitive landscapes ... The landscape that we all see from our windows and cars is actually a food factory which has been crafted by men with hedges and fields.

This unromanticised view of the landscape comes with a strong critique of the efforts by the National Trust and other organisations to preserve local distinctiveness and limit built development in Cornwall. Instead, the view is that decisions should be made on the basis of what is rationally necessary to address the pressures local communities are facing. In this productive landscape narrative, human interventions and larger-scale built features in the landscape are not viewed as visual disturbances. The aim of landscape management is seen as making ideal use of Cornwall's natural environment for farming and food production. The strong focus on preservation of the relicts of past human activities in the landscape is perceived as an impediment to sustainable development rather than as having a positive influence.

The four narratives presented in the previous paragraphs construct Cornwall's landscapes very differently and are in parts strongly divergent. An alternative narrative often encountered in the context of coastal erosion is the one of anxiety and loss (see e.g. Adger et al. 2014) - this perspective, however, was not featured in the interviews in Cornwall. From the four viewpoints outlined above result equally diverse approaches for landscape management in times of a changing climate. To highlight the narratives' relevance for climate adaptation, we will now outline how climate change is being understood from the different perspectives and what implications these understandings have for the implementation of adaptation measures.

\section{Implications for climate change adaptation}

As outlined on p. the Cornwall case study shows that a common attachment to and appreciation for a landscape are not necessarily predictors for a consensus on how best to manage it. By identifying contrasting narratives about the local landscapes, we show clearly that Cornwall as a place is conceptualised very differently by different actors, with diverse implications for landscape management, especially under climate change; and for how adaptation activities are operationalised in practical terms. Cornwall Council's policy narrative underlines the '... need to protect the quality and natural beauty, including the landscape ... for its own sake but also as an economic driver and to build and 
maintain resilience to climate change' (Cornwall Council 2016, 17).

Although climate change is framed as a potential threat both to Cornwall's historic heritage and current settlements (Cornwall Council 2015b; Environment Agency 2012), references to climate change in the Council's policy documents seem rather perfunctory in terms of actual practical recommendations. Coordinated efforts by local government to approach adaptation in the region thus appear to be in their early stages and as yet a transformative perspective on adaptation has not been developed in Cornwall.

Whereas a consistent policy narrative about climate change does not exist in Cornwall, the three coexisting narratives about Cornwall's landscapes provide key insights into the management implications of landscape change with direct relevance for climate adaption. In the natural landscape narrative climate change, even if anthropogenically accelerated, is part of a natural cycle and therefore inevitable. Whereas the notion of preserving the landscape features in both the policy and the natural landscapes narrative, the need for preservation in the latter is limited to the protection of the natural environment. Consequently, responses to climate change should focus predominantly on creating sustainable ecosystems and healthy wildlife through suitable management of the natural landscape, a view shared by Cornwall Wildlife Trust and Natural England.

You know, our work is about climate change adaptation largely ... So one of the challenges in climate change adaptation is to look after the wildlife that we've got ... It's one of the reasons why we do what we do, to look after it.

\section{Interviewee 1, Natural England}

The imperative to manage the natural landscape sustainably is expressed in terms of a strong sense of stewardship over the natural environment. The natural systems narrative thus operationalises climate change adaptation through working with or restoring natural processes wherever possible and protecting the landscape from harmful human interventions such as hard engineering structures, especially regarding coastal protection and the alleviation of river flooding.

Landscape management in the lived landscape narrative is seen as a process of co-adaptation of the landscape and human practice in it. Central to this narrative is a criticism of the detachment of society from nature and the call to reverse this division. Regarding climate change, this emphasis on lived landscapes results in a call for locally embedded, bottom-up initiatives and community projects which focus on the local population as key actors for change. An effective response to climate change is understood in terms of drawing on local knowledge and reattaching people to the physical environment in which they live:

They [communities] are our new partners in flood management. They will have a key role in adaptation because they understand their local landscape ... And that's important sometimes, to work with the people and make them understand how they work in the landscape and how the landscape works around them.

Interviewee 17, Environment Agency

Building resilience to climate change is perceived as joint adaptation of the landscape itself and, maybe more importantly, the ways in which communities live in and shape their places. From a human-environment interaction perspective, climate change adaptation is therefore understood in terms of community-led initiatives and the reconnection of people with the landscape they shape and are shaped by. Examples for such adaptation activities are capacity building around flood protection through a community flood forum and the installation of household-level installations such as flood gates and suitable drainage systems.

From the viewpoint of the productive landscape narrative, the impacts that climate change is likely to have on Cornwall's landscapes correspond with the perception of the dominance of the human system over the natural: 'I think there will be small changes from natural means, and big ones from men' (Interviewee 3, Parish Councillor). To the interviewees following this narrative, built features such as renewable energy infrastructure do not impact negatively on the landscape. On the contrary, Interviewee 4 sees the suitable response to climate change in engineered solutions:

Climate change is a real issue and I worry deeply about it ... In order to mitigate the effects of climate change we need engineering solutions .... And we do accept them in our day-to-day lives! We also accept road infrastructure which is a horrendous scar in the landscape.

Although appreciating the attractiveness of the Cornish landscapes, he heavily criticises the strong prevalent focus on preservation. It is exactly this tendency towards conserving the status quo, he argues, which is a barrier to adequately addressing climate change in Cornwall:

Some people get really obsessed with preventing change ... We can't stand still, and so the landscape will inevitably change ... I think the inherent sort of falling back upon the Cornishness ${ }^{5}$ is an impediment to doing something about climate change because we won't 
accept the big engineering solutions that we'd need for a change.

Interviewee 4, Cornwall Councillor

This utilitarian perspective on Cornwall's landscapes results in the demand for addressing climate change through mitigation infrastructure such as large wind turbines on the one hand and through effective flood alleviation measures on the other, even if visible in the landscape.

\section{Conclusions}

Drawing on qualitative interviews with decisionmakers from landscape management organisations in Cornwall (UK), we discovered local narratives about Cornwall's landscapes as natural systems, human-environment interaction and spaces of production. These constructions stand in surprising contrast to each other and to the way in which the region is portrayed by its Council. Most notably, however, they dig under the surface of the images of Cornwall presented in popular media and the tourism sector as an area characterised by natural beauty and industrial heritage. We furthermore showed that people's shared appreciation of places and landscapes is not a guarantee for agreement about their management under a changing climate. The three competing narratives about Cornwall's landscapes reveal that divergent understandings of landscapes result in very different demands for adaptation activities. By comparing the narratives' implications for landscape management, it becomes clear that the concept of 'landscape' even if superficially understood as one and the same thing - has various meanings for different actors in landscape management. The green fields and hedges, for example, which are seen as wildlife habitat in one narrative, are perceived as an industrialised food factory in another. Moreover, it becomes clear that the classification of landscapes as 'natural' or 'cultural' is highly subjective and depends on the perspective from which a landscape is viewed. Instead of making this distinction, we argue, all landscapes should be understood as cultural constructs aligned along different stories about the same material space.

Resulting from these different constructions of landscapes arise contrasting perspectives on how they are affected by climate change. Thus, the different narratives have significant potential implications for resulting physical-material alterations of Cornwall's landscapes. From preserving the status quo and rejecting any built interventions through a focus on community-led action, to a call for hard engineering - different constructions of landscapes result in potentially conflicting demands for adaptation measures. As O'Brien (2009) argues, this is especially important when adaptation activities proposed by one group or organisation negatively impact on what another group value about a landscape. Not only does climate change thus alter places physically, it also has the potential to interfere with attachments and cultural values - people's mental constructions of those places also influence how they choose to adapt to a changing climate. Although the insight that different people perceive landscapes differently is not new, we could show that unravelling competing landscape constructions provides valuable insights into the unspoken assumptions that underlie decisions around climate change adaptation. Our findings thus contribute to bridging the gap between the theoretical considerations of constructivist landscape research in the academic realm and the policy relevance of different landscape constructions amongst practitioners in landscape management. By placing the focus on the different ways in which a landscape is perceived and emotions are articulated in relation to it, perceptions of change, and the resulting management implications, a narrative approach to researching societal processes of climate adaptation serves a twofold purpose. On the one hand, it enhances our understanding of how people make sense of their everyday, lived- and worked-in landscapes and changes to them, by uncovering their reasoning behind adaptation decisions and grounding those decisions in their perceptions of, and relationships with, the places where climate change happens. On the other hand, it contributes to overcoming the divide between the 'expert' knowledge of professionals in landscape management, often referred to as rational and more 'legitimate', and the viewpoints of the local population deeply connected to the landscape through emotional attachment and everyday practices (also Geoghegan and Leyshon 2014). Thus, this paper furthers existing work on the role of place attachments in societal responses to climate change by laying open the wider storylines behind different approaches to climate adaptation and their implications for physical-material adaptation activities.

The fact that none of the narratives derived from the interviews can clearly be attributed to staff of one specific organisation highlights both the importance that individual perceptions of place and landscape have in decisionmaking on the local level as well as the need to understand how such personal perceptions differ. Uncovering different constructions of local landscapes, however, is only a first step to better understanding the role of peopleplace relationships in adaptive management. Analysing different landscape narratives in more detail and revealing the underlying understandings of nature, climate and human-environment relationships constitutes an important next step towards comprehending the diverse rationalities behind 
different approaches to climate adaptation. Viewing the narratives as a starting point, smaller-scale case studies of ongoing adaptation activities could unveil how different actors' constructions of particular landscapes translate into the implementation of physical-material changes to places. To understand the societal dynamics of negotiating landscapes in times of a changing climate better, moreover, further research should examine the consideration of different understandings of landscape and climate change in local decisionmaking and the politics, power relations, and responsibilities connected with these different viewpoints.

Leaving unarticulated the taken-for-granted constructions that landscape management actors have of their local landscapes holds great potential for misunderstandings and can constitute an obstacle for sustainable adaptation governance - especially, as Fresque-Baxter and Armitage (2012) argue, when adaptation measures implemented by one group of people threaten what another group holds dear about a place. We therefore argue in line with Agyeman et al. (2009) and Soliva (2007) that a better comprehension of the contrasting constructions of places can help to foster constructive dialogue between different actors in landscape and adaptive management and to consider diverse epistemologies of landscape, nature and climate change in decisionmaking and policy formulation. In Cornwall, such dialogue could well be based on the shared strong attachment to the area, but accentuate contrasting understandings of the local landscapes. Working out how these perceptions can be laid open, challenged and integrated into decisionmaking processes around climate change adaptation would thus be an important step towards a more interdisciplinary approach to joint landscape management in times of a changing climate.

\section{Acknowledgements}

This research was supported through the Cluster of Excellence 'CliSAP' (EXC177), Universität Hamburg, funded through the German Science Foundation (DFG). Many thanks to the editor and the anonymous reviewers for their thorough and useful comments.

\section{Notes}

1 In the Cornwall case study, the main actors in landscape management were identified as Cornwall Council, the Environment Agency, the National Trust, Natural England, Cornwall Wildlife Trust, the AONB Partnership, parish councils, as well as larger tourism organisations.

2 Although we are keenly aware of the multiple possible connotations of the word 'landscape', we deliberately did not provide the participants with a definition of the term prior to the interviews. Following a constructivist epistemology, the focus of our research lay on uncovering the interviewees' subjective interpretations of the phenomenon.

3 Areas of Outstanding Natural Beauty (AONB) or Natural England Site of Special Scientific Interest (SSSI)

4 For practical reasons, we focused on the perspective of Cornwall Council for identifying the official policy narrative. We acknowledge that organisations such as the National Trust and Natural England are part of the wider policy context in Cornwall. As their understandings of the Cornish landscape differ from those of Cornwall Council, however, we chose to represent their views through the narratives which we contrast to the official policy one.

5 By Cornishness, he refers to the region's strong identification with its past and heritage, resulting in a preservation approach to landscape management.

\section{References}

Adger W N, Barnett J, Brown K, Marshall N and $\mathrm{O}^{\prime}$ Brien K 2013 Cultural dimensions of climate change impacts and adaptation Nature Climate Change 2 112-17

Adger W N, Barnett J, Chapin III F S and Ellemor H 2011 This must be the place: underrepresentation of identity and meaning in climate change decision-making Global Environmental Politics 2 1-25

Adger W N, Dessai S, Goulden M, Hulme M, Lorenzoni I, Nelson D R, Naess L-O, Wolf J and Wreford A 2009 Are there social limits to adaptation to climate change? Climatic Change 3 335-54

Agyeman J, Devine-Wright P and Prange J 2009 Close to the edge, down by the river? Joining up managed retreat and place attachment in a climate changed world. Environment and Planning A 3 509-31

Alkon A H 2004 Place, stories, and consequences Organization and Environment 2 145-69

Amundsen H 2015 Place attachment as a driver of adaptation in coastal communities in Northern Norway Local Environment: The International Journal of Justice and Sustainability 3 257-76

Beer H 2016 Poldark: behind the scenes National Trust Magazine autumn 2016 (www.nationaltrust.org.uk/features/c ornish-coast-stars-in-poldark-remake) Accessed 29 September 2016

Berger P and Luckmann L 1966 The social construction of reality Anchor Books, New York

Brace C and Geoghegan H 2010 Human geographies of climate change: landscape, temporality, and lay knowledges Progress in Human Geography 5 284-302

Burley D, Jenkins P, Laska S and Davis T 2007 Place attachment and environmental change in coastal Louisiana Organization and Environment 3 347-66

Climate UK 2012 A summary of climate change risks for South West England (http://climateuk.net/resource/regional-summa ries-uk-climate-change-risk-assessment) Accessed 26 June 2015

Cornwall AONB Partnership 2011 Cornwall AONB management plan 2011-2016. Further Information to each strategic chapter: web-based appendices. 3: Climate change and energy Truro 
Cornwall Council 2011 Cornwall landscape character: best practice guide (www.cornwall.gov.uk/media/3627266/La ndscape_Best_Practice_Aug_2011_Full-version-Web.pdf) Accessed 3 March 2016

Cornwall Council 20122011 Census at a glance (www.cornwa II.gov.uk/council-and-democracy/data-and-research/data-by -topic/2011-census/) Accessed 14 June 2016

Cornwall Council 2014 Environment and planning - Cornwall's landscape (www.cornwall.gov.uk/environment-and-planning/ cornwalls-landscape/) Accessed 3 March 2016

Cornwall Council 2015a Landscape character assessment 2007 (www.cornwall.gov.uk/environment-and-planning/cornwallslandscape/landscape-character-assessment-2007/) Accessed 3 March 2016

Cornwall Council 2015b What are the potential impacts of climate change in Cornwall? (www.cornwall.gov.uk/environ ment-and-planning/sustainable-development/climate-changeand-energy/what-are-the-potential-impacts-of-climate-changein-cornwall/) Accessed 3 March 2016

Cornwall Council 2016 Cornwall local plan (www.cornwa Il.gov.uk/media/17155253/local-plan-combined-version-jan2016-small.pdf) Accessed 22 March 2016

Daniels D and Endfield G 2009 Narratives of climate change: introduction Journal of Historical Geography 35 (special issue) $215-22$

DeSilvey C 2012 Making sense of transience: an anticipatory history Cultural Geographies 1 31-54

Devine-Wright P 2013 Think global, act local? The relevance of place attachments and place identities in a climate changed world Global Environmental Change 1 61-9

Devine-Wright P 2014 Dynamics of place attachment in a climate changed world in Manzo L $\mathbf{C}$ and Devine-Wright $\mathbf{P}$ eds Place attachment Routledge, Oxford, New York

Devine-Wright P 2015 Local attachments and identities: a theoretical and empirical project across disciplinary boundaries Progress in Human Geography 4 527-30

Environment Agency 2012 West Cornwall catchment flood management plan. Summary report June 2012 Exeter

Feldman M, Sköldberg K, Brown R N and Horner D 2004 Making sense of stories: a rhetorical approach to narrative analysis Journal of Public Administration 14 147-70

Fresque-Baxter J and Armitage D 2012 Place identity and climate change adaptation: a synthesis and framework for understanding WIREs Climate Change 3 251-66

Gailing L 2012 Dimensions of the social construction of landscapes - perspectives on new institutionalism Proceedings of the Latvian Academy of Sciences, Section A Social Sciences and Humanities 3 195-205
Gailing L and Leibenath M 2015 The social construction of landscapes: two theoretical lenses and their empirical applications Landscape Research 2 123-38

Geoghegan H and Leyshon C 2014 Shifting shores: managing challenge and change on the Lizard Peninsula, Cornwall, UK Landscape Research 6 631-46

Greider T and Garkovich L 1994 Landscapes: the social construction of nature and the environment Rural Sociology $11-24$

Hajer 1995 The politics of environmental discourse: ecological modernization and the policy process Calderon Press, Oxford

Ingold T 2010 The temporality of the landscape in Preucel $\mathbf{R}$ W and Mrozowski S A eds Contemporary archaeology in theory: the new pragmatism Wiley-Blackwell, Chichester, UK

Kilper H and Gailing L 2013 Die politische Konstruktion von Kulturlandschaften als kollektive Handlungsräume in Leibenath $\mathbf{M}$, Heiland $\mathbf{S}$, Kilper $\mathbf{H}$ and Tzschaschel $\mathbf{S}$ eds Wie werden Landschaften gemacht? transcript Verlag, Bielefeld

Kühne 2013 Landschaftstheorie und Landschaftspraxis Springer, Wiesbaden

Leyshon C and Geoghegan H 2012 Anticipatory objects and uncertain imminence: cattle grids, landscape and the presencing of climate change on the Lizard Peninsula, UK Area 44 237-44

Leyshon $\mathbf{C}$ and Walker $\mathbf{T}$ forthcoming Framing risk: implications for delivering the ecological network approach in landscape management Global Environmental Change

O'Brien K 2009 Do values subjectively define the limits to climate change adaptation? in Adger W N, Lorenzoni I and O'Brien K eds Adapting to climate change Cambridge University Press, Cambridge

Ratter B and Gee K 2012 Heimat - a German concept of regional perception and identity as a basis for coastal management in the Wadden Sea Ocean \& Coastal Management 127-37.

Richie J and Lewis J eds 2003 Qualitative research practice Sage Publications, London, Thousand Oaks, New Delhi

Soliva R 2007 Landscape stories: using ideal type narratives as a heuristic device in rural studies Journal of Rural Studies 62-74.

Tomaney J 2015 Understanding parochialism: a response to Patrick Devine-Wright Progress in Human Geography 4 53132

Walker A J and Ryan R L 2008 Place attachment and landscape preservation in rural New England: a Maine case study Landscape and Urban Planning 2 141-52 


\section{Author Query Form}

\section{Journal:}

\section{GEOJ}

Article:

Dear Author,

During the copy-editing of your paper, the following queries arose. Please respond to these by marking up your proofs with the necessary changes/additions. Please write your answers on the query sheet if there is insufficient space on the page proofs. Please write clearly and follow the conventions shown on the attached corrections sheet. If returning the proof by fax do not write too close to the paper's edge. Please remember that illegible mark-ups may delay publication. Many thanks for your assistance.

\begin{tabular}{|l|l|c|}
\hline Query reference & Query & Remarks \\
\hline 1 & $\begin{array}{l}\text { AUTHOR: Please confirm that given names (red) and surnames/family } \\
\text { names (green) have been identified correctly. }\end{array}$ & Yes \\
\hline 2 & AUTHOR: Please give reference details for Natural England (2011). & See p. 2 \\
\hline 3 & $\begin{array}{l}\text { AUTHOR: Please update the text 'As outlined on p. xx,', which appears } \\
\text { twice. }\end{array}$ & done \\
\hline 4 & AUTHOR: Please give reference details for Rose and Wiley (2006) & see p. 6 \\
\hline 5 & AUTHOR: Please give page numbers for Devine-Wright (2014). & \\
\hline 6 & AUTHOR: Please give page numbers for Ingold (2010). & see p. 12 \\
\hline 7 & AUTHOR: Please give page numbers for Kilper and Gailing (2013). & \\
\hline 8 & AUTHOR: Please give page numbers for O'Brien (2009). & \\
\hline 9 & AUTHOR: Please give volume number for Ratter and Gee (2012). & \\
\hline 10 & AUTHOR: Please give volume number for Soliva (2007). & \\
\hline
\end{tabular}




\section{Author Services}

Wiley-Blackwell Author Services can be accessed by visiting

http://authorservices.wiley.com/bauthor/ or by following the link from your email.

Wiley-Blackwell Author Services allows you to track the production status of your accepted articles, add co-authors and distribute your articles to your colleagues.

Register for an account now. You'll have the chance to sign up for additional alerts at key stages, or you may just log in from time to time to check on your article's status.

Please note that you must have received an e-mail from a journal with your article ID in order to track the production status of your article. The format of the Unique ID is 123456-123456. Unfortunately the ScholarOne Manuscripts tracking number is separate and will not work in Author Services.

If you wish to submit a manuscript to the editorial office for review, please use the "Guidelines by Journal" at the right to find the specific journal.

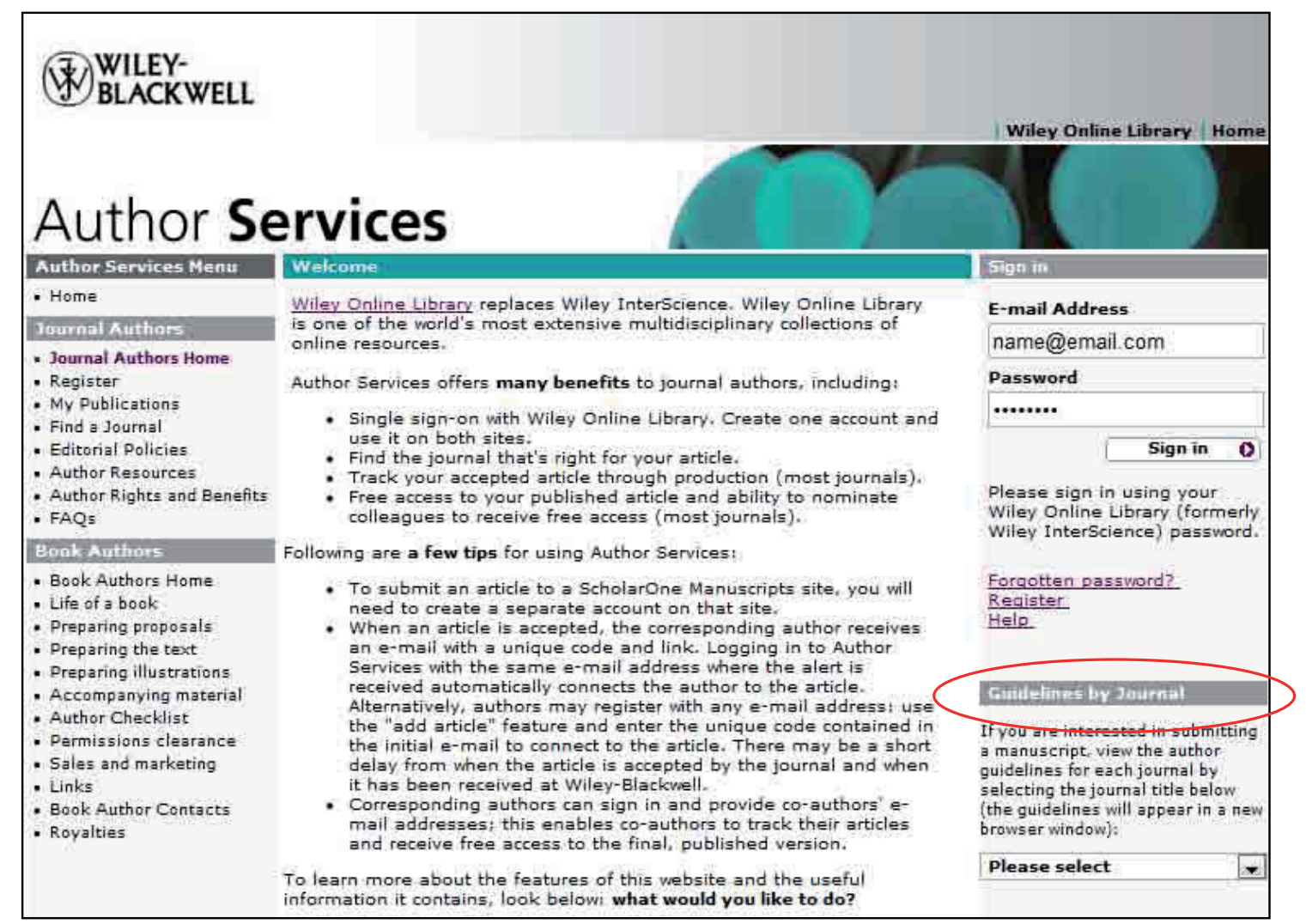

The instructions contain the link to the manuscript submission website if applicable, which is separate from Author Services. If the journal does not offer online submission, the instructions will contain the address to which you should send your manuscript

Once you have received an article ID, you can add an article to your profile:

1. If you have previously registered in Author Services, click on the link in the e-mail and log in. If your login (e-mail address) matches the address where the initial alert was sent, then you will be connected automatically to your article. 
2. If you have never registered, click on the link in the e-mail and register. If your username (email address) matches the address where the initial alert was sent, you'll be connected automatically to your article.

3. If you wish to register at an e-mail address other than the one to which the alert was sent, you can add the article to your profile by following the instructions below.

\section{Add an article}

To add an accepted article to your My Publications profile, click on the 'Add a new article' button and enter the Unique ID for your article. This is included in your initial email alert and the format is 123456-123456. If you have forgotten or mislaid your article code, please contact e-help.

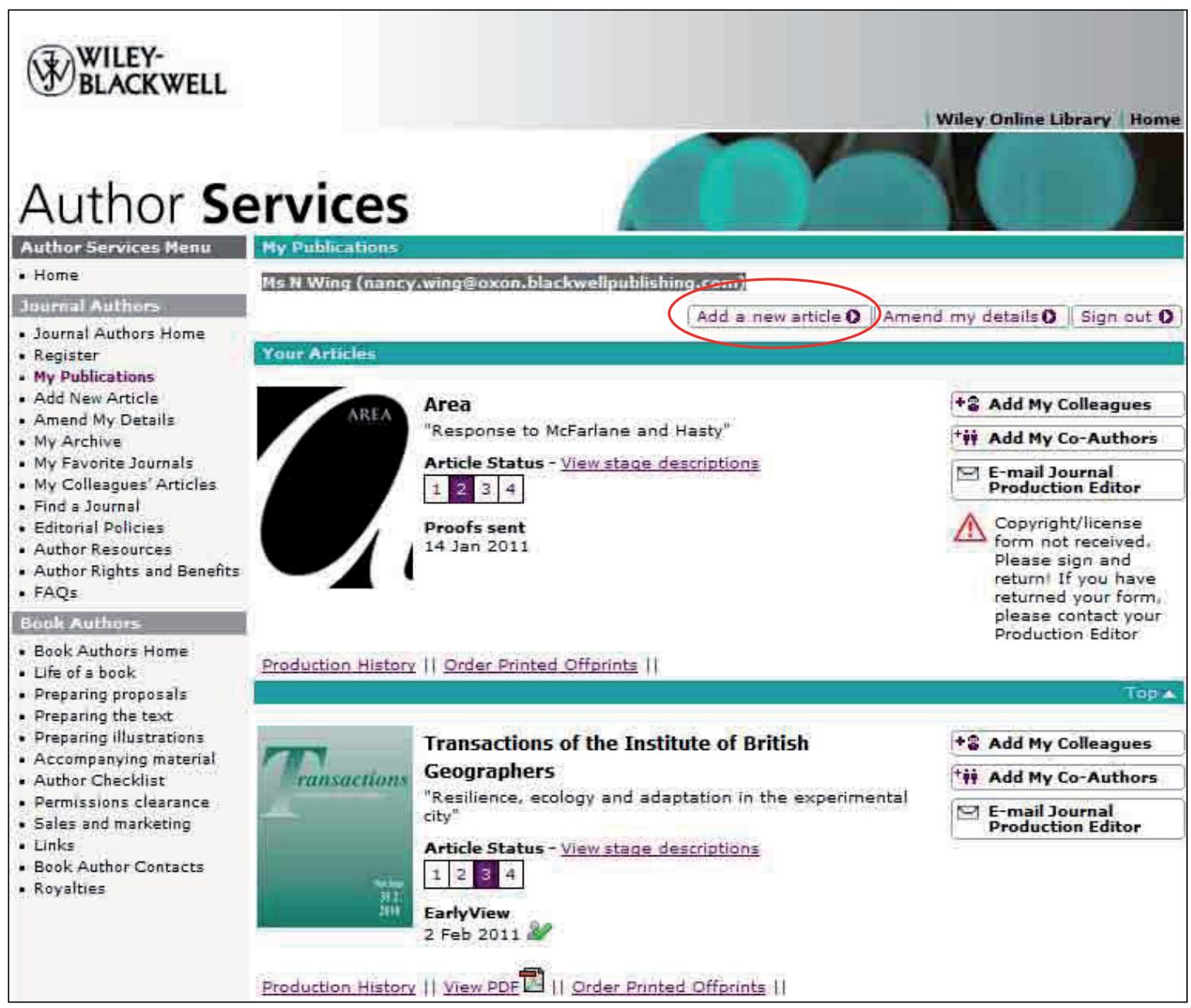

Once you have added your article, you can track its current article status, view its production history, and order printed offprints.

The four stages you are able to track your article through are:

- Accepted article received

- Proofs sent

- Corrections received

- Issue published online 
If your article is published as Early View online prior to appearing in an issue, a further notification will appear below the Article Status tracker and a 'View PDF' link will be added to allow you to view your article.

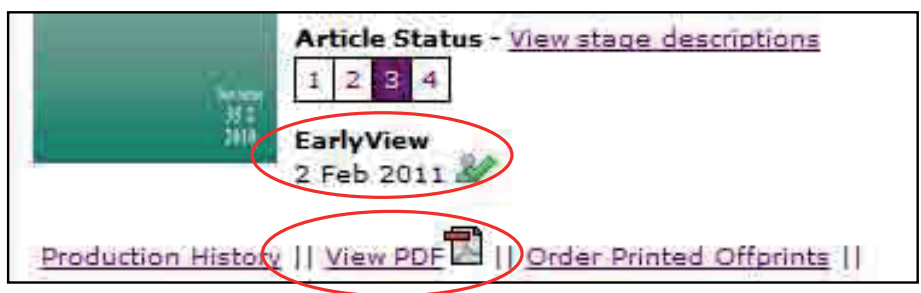

\section{Add My Colleagues}

Enter the e-mail addresses of up to 10 colleagues to disseminate your paper to key readers. An invitation to register in Author Services will be sent to each colleague to invite him or her to view your article once it has been published online. If your colleague has already registered in Author Services, the e-mail will contain instructions on how to add

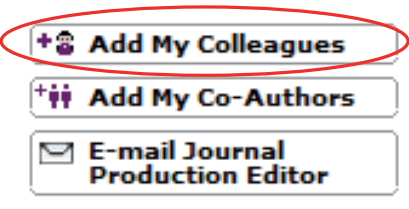
the article to his or her account. The e-mail address will not be used for anything other than an invitation to register in Author Services. This feature is designed to support article usage as well as citations. Online usage is becoming increasingly important, so we encourage you to take advantage of this way of promoting your article.

\section{Add My Co-Authors}

Enter the e-mail addresses of your co-author(s). An invitation to register in Author Services will be sent to each co-author so he or she can track production and view the article online using separate log-in details from yours. If your co-author has already registered in Author Services, the e-mail will contain instructions on how to add the article to his or her account. The e-mail address will not be used for anything other than an invitation to register in Author Services.

\section{E-mail Journal Production Editor}

If you have any concerns over the progress of your article, you can use this button to contact the production editor directly.

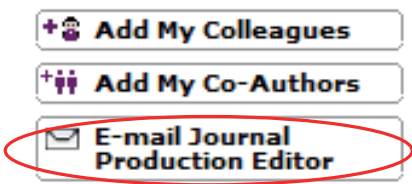

